\title{
IONIC LIQUID-FUNCTIONALIZED TITANOMAGNETITE NANOPARTICLES AS EFFICIENT AND RECYCLABLE CATALYST FOR GREEN SYNTHESIS OF 2,3-DIHYDROQUINAZOLIN-4(1H)-ONES
}

\author{
Davood Azarifar ${ }^{1}$, Omolbanin Badalkhani ${ }^{1}$, Morteza Chehregosha ${ }^{1}$, \\ Mehdi Jaymand ${ }^{2, 凶}$
}

https://doi.org/10.23939/chcht14.01.062

\begin{abstract}
In the present study, titanomagnetite nanoparticles $\left(\mathrm{Fe}_{3-\mathrm{x}} \mathrm{Ti}_{\mathrm{x}} \mathrm{O}_{4} \mathrm{NPs}\right)$ were synthesized via coprecipitation approach and then functionalized using 3trimethoxysilylpropyl chloride silan coupling agent followed by tetrabutylammonium asparaginate through a facial and newly one-pot procedure to afford an ionic liquid (IL)-modified $\mathrm{Fe}_{3-\mathrm{x}} \mathrm{Ti}_{\mathrm{x}} \mathrm{O}_{4} \mathrm{NPs}$. The synthesized NPs were examined as potent and recyclable nanocatalysts for one-pot three-component synthesis of 2,3-dihydroquinazolin- $4(1 \mathrm{H})$-ones under solvent-free conditions. Easy magnetic separation and efficient recyclability of the catalyst, excellent yields of the reactions, low reaction times as well as solvent-free conditions are the most important advantages of the present procedure that qualified the fabricated $\mathrm{Fe}_{3-\mathrm{x}} \mathrm{Ti}_{\mathrm{x}} \mathrm{O}_{4} \mathrm{NPs}$ as a nanocatalyst for industrial applications.
\end{abstract}

Keywords: ionic liquid, titanomagnetite nanoparticles, nanocatalyst, green chemistry, organic synthesis.

\section{Introduction}

Among the heterogeneous catalysts reported in the literature for the synthesis of organic compounds, inorganic nanoparticles (NPs) (e.g., magnetic NPs) are of considerable interest as efficient catalysts and supports. This intense interest is originated from their extraordinary properties including a nano-scaled size, high surface-tovolume ratio, and coordinated parts which provide a large number of active sites per unit area in comparison with their corresponding microparticles $[1,2]$.

It is an unquestionable fact that the use of homogeneous catalysts are subjected to tedious separation by filtration or centrifugation that is required to avoid the contamination of the final products with residual metal

\footnotetext{
${ }^{1}$ Department of Chemistry, Bu-Ali Sina University, 65178 Hamedan, Iran

${ }^{2}$ Immunology Research Center, Tabriz University of Medical Sciences,

Tabriz, Iran

m.jaymand@gmail.com

(C) Azarifar D., Badalkhani O., Chehregosha M., Jaymand M., 2020
}

especially in the case of pharmaceuticals [3]. In addition, from economic and environmental points of view, the design and development of recyclable and eco-friendly heterogeneous catalysts is necessary for industrial processes. In this respect, magnetic (MNPs) have found applications as catalysts or supports for various reactions [4-8]. In recent years, numerous metal oxide NPs with high performance of magnetic properties have been developed and widely used as magnetic data storage, bio/chemical sensors, environmental sciences, sorbents, biomedical fields, as well as catalysts [9-12]. In this context, titanomagnetite $\left(\mathrm{Fe}_{3-\mathrm{x}} \mathrm{Ti}_{\mathrm{x}} \mathrm{O}_{4}\right)$ NPs is of particular interest, because the presence of $\mathrm{Ti}^{4+}$ cations in its structure leads to significant increasing the relative number of surface hydroxyl groups [13]. It is well established that, incorporation of some transient metals (e.g., $\mathrm{Mn}, \mathrm{Cr}, \mathrm{Co}, \mathrm{V}$, and Ti) into $\mathrm{Fe}_{3} \mathrm{O}_{4}$ NPs significantly improve their physicochemical features. These nanomaterials have received a great deal of scientists attentions for different applications such as environmental engineering, mineralogy and material sciences [13-18].

Nevertheless, the main issue regarding the application of these NPs is their quick aggregation into large bunches that lead to lose their unique properties. This thematic issue can be solved through the surface modification using organic or inorganic components such as $\mathrm{SiO}_{2}$ or silan coupling agents to form core-shell structures [19-21].

On the other hand, the surface modification of these NPs using ionic liquids (ILs) is another strategy for improving the catalytic function of these nanomaterials in organic reactions and industrial processes. The promising advantages of this strategy are environmental benignity, high thermal stability, high catalytic efficiency, reusability, negligible vapor pressure, low viscosity, easy handling and separation from the products due to their heterogeneous behavior [22-25].

Quinazolinone has attracted great deal of academic and industrial interest as an exciting motif mainly due to its pharmacological and therapeutic importance as an 
effective anticonvulsant [26], anti-inflammatory [27, 28], analgesic and cyclooxygenase-2 (COX-2) inhibitor [2933], anti-cancer [34, 35], anti-hypertensive [36], antimalarial [37], antimicrobial [38] and diuretic activities [39]. In addition, quinazolinone nucleus exists as a building block in many naturally occurring alkaloids [40]. 2,3-Disubstituted quinazolin-4(3H)-ones have been reported to exhibit remarkable anticonvulsant, analgesic and anti-inflammatory activities. Also, 1,2-dihydroquinazolinones were reported to possess greater potent activity compared to fully aromatic quinazolinones [41].

Numerous strategies have been reported for the synthesis of 2,3-dihydroquinazolin-4(1H)-ones in the literature using various catalytic systems and reaction conditions [42-52]. In this investigation, IL-modified $\mathrm{Fe}_{3-\mathrm{x}} \mathrm{Ti}_{\mathrm{x}} \mathrm{O}_{4}$ NPs were applied as a recyclable and heterogeneous nanocatalyst for the one-pot three-component synthesis of 2,3-dihydroquinazolin-4(1H)-onesunder solvent-free conditions. The effect of some parameters including solvent, time, and temperature on the yield of reactions was also examined.

\section{Experimental}

\subsection{General}

All solvents used were strictly dried according to standard operations and stored over $4 \AA$ molecular sieves. Other chemicals were purchased from Merck (Darmstadt, Germany) and used as received without further purification. Melting points were determined in open capillaries using a BUCHI 510 apparatus (Flawil, Switzerland). Fourier transform infrared (FTIR) spectra were recorded using $\mathrm{KBr}$ pellets on a Shimadzu 435-U-04 FT-IR spectrometer (Kyoto, Japan). ${ }^{1} \mathrm{H}$ and ${ }^{13} \mathrm{C}$ NMR spectra were obtained on 400 and $100 \mathrm{MHz}$ Bruker instrument (Bruker, Ettlingen, Germany), respectively, in DSMO- $d_{6}$ as a solvent and tetramethylsilane (TMS) as an internal standard. Mass spectra (MS) were recorded by a FINNIGAN-MAT 8430 spectrometer (Bremen, Germany) operating at an ionization potential of $70 \mathrm{eV}$.

\subsection{Catalyst Synthesis}

\subsubsection{Synthesis of tetrabutylammonium asparaginate (TBAAsp) ionic liquid}

Tetrabutylammonium asparaginate ionic liquid was synthesized according to previously reported modified procedure [53] (Scheme 1) as follows: a solution of $L$-asparagine amino acid $(2.64 \mathrm{~g}, 20 \mathrm{mmol})$ in distilled water $(20 \mathrm{ml})$ was ultrasonicated for $20-30 \mathrm{~min}$ at room temperature to give an aqueous suspension. Then, an aqueous solution of tetrabutylammonium hydroxide (TBAOH; 40\% w/v; $5.2 \mathrm{ml} ; 20 \mathrm{mmol}$ ) was added under vigorous stirring and the resulted mixture was refluxed for $24 \mathrm{~h}$. Afterward, the mixture was cooled to room temperature, the water was removed using a rotary evaporator under reduced pressure and the mixture containing unreacted asparagine amino acid and desired ionic liquid was diluted with chloroform $(10 \mathrm{ml})$. Finally, the mixture was filtered to separate the remaining amino acid, and the filtrate was dried in air to yield the yellow viscose ionic liquid. The spectral data $\left({ }^{1} \mathrm{H}\right.$ NMR, ${ }^{13} \mathrm{C}$ NMR and MS) of the synthesized ionic liquid are given below.

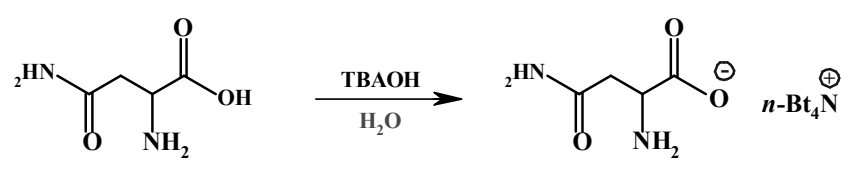

Scheme 1. Synthesis of tetrabutylammonium asparaginate (TBAAsp) ionic liquid

Spectral data of the synthesized tetrabutylammonium asparaginate (TBAAsp) ionic liquid. Yellow viscose liquid. FTIR (KBr) v: 3383, 3295, 2967, 2941, 2875, 1667, 1578, 1490, 1468, $1366 \mathrm{~cm}^{-1}$. ${ }^{1} \mathrm{H}$ NMR $\left(400 \mathrm{MHz}, \mathrm{DMSO}-d_{6}\right) \delta: 0.95\left(\mathrm{t}, 12 \mathrm{H}, 4 \mathrm{CH}_{3}\right), 1.31-1.33$ $\left(\mathrm{m}, 8 \mathrm{H}, 4 \mathrm{CH}_{2}\right), 1.58\left(\mathrm{~m}, 8 \mathrm{H}, 4 \mathrm{CH}_{2}\right), 1.88-1.95(\mathrm{dd}, 1 \mathrm{H}$, $\mathrm{H}_{2} \mathrm{NC}(\mathrm{O})-\mathrm{CH}$ ), 2.42-2.43 (dd, $\left.1 \mathrm{H}, \mathrm{H}_{2} \mathrm{NC}(\mathrm{O})-\mathrm{CH}\right), 3.17-$ $3.22\left(\mathrm{~m}, 8 \mathrm{H}, 4 \mathrm{CH}_{2}\right), 3.59$ (dd, $\left.1 \mathrm{H}, \mathrm{H}_{2} \mathrm{~N}-\mathrm{CH}\right), 5.1,6.32$ $\left(4 \mathrm{H}, 2 \mathrm{NH}_{2}\right) \mathrm{ppm} .{ }^{13} \mathrm{C}$ NMR $\left(100 \mathrm{MHz}\right.$, DMSO- $\left.d_{6}\right) \delta: 13.9$ $\left(\mathrm{CH}_{3}\right), 19.7\left(-\mathrm{CH}_{2}\right), 23.6\left(-\mathrm{CH}_{2}\right), 44.3\left(\mathrm{CH}_{2}\right), 54.2(\mathrm{HC}-$ $\left.\left.\mathrm{NH}_{2}\right), 57.9\left(-\mathrm{CH}_{2}\right), 174.9 \mathrm{C}(\mathrm{O})-\mathrm{NH}_{2}\right), 175.4\left(\mathrm{COO}^{-}\right) \mathrm{ppm}$. MS $(70 \mathrm{eV}), m / z=373.4$.

\subsubsection{Synthesis of $\mathrm{Fe}_{3-\mathrm{x}} \mathrm{Ti}_{\mathrm{x}} \mathrm{O}_{4} \mathrm{MNPs}$}

Titanomagnetite nanoparticles $\left(\mathrm{Fe}_{3-\mathrm{x}} \mathrm{Ti}_{\mathrm{x}} \mathrm{O}_{4} \mathrm{NPs}\right)$ were synthesized following the approach reported in the literature $[16,55]$. A solution of $\mathrm{FeSO}_{4} \cdot 7 \mathrm{H}_{2} \mathrm{O}(3.81 \mathrm{~g}$, $13.6 \mathrm{mmol})$ in deionised water $(18 \mathrm{ml})$ was prepared and its $\mathrm{pH}$ value was adjusted to $<1$ by adding $\mathrm{HCl}$ solution $(1 \mathrm{M} ; 7 \mathrm{ml}) . \mathrm{TiCl}_{4}(1.6 \mathrm{ml})$ and hydrazine monohydrate $(2 \mathrm{ml})$ were added dropwise to this solution. The resulted mixture was refluxed at $363 \mathrm{~K}$ for $30 \mathrm{~min}$ under inert atmosphere. Then, an aqueous solution of $\mathrm{NaOH}(4.0 \mathrm{~g})$ and $\mathrm{NaNO}_{3}(2.0 \mathrm{~g})$ in $18 \mathrm{ml}$ of deionised water was added to the mixture under vigorous stirring and refluxed for $1 \mathrm{~h}$. Finally, the resulting mixture was cooled to room temperature using ice/water bath to precipitate the titanomagnetite nanoparticles which were magnetically separated, washed with distilled water and dried under reduced pressure at room temperature. 


\subsubsection{Synthesis of IL-functionalized $\mathrm{Fe}_{3-\mathrm{x}} \mathrm{Ti}_{\mathrm{x}} \mathrm{O}_{4} \mathrm{MNPs}$}

The surface of the synthesized $\mathrm{Fe}_{3-\mathrm{x}} \mathrm{Ti}_{\mathrm{x}} \mathrm{O}_{4} \mathrm{NPs}$ was functionalized using 3-trimethoxysilylpropyl chloride (TMSP-Cl) followed by the synthesized tetrabutylammonium asparaginate ionic liquid via a facial one-pot process [54]. For this purpose, $\mathrm{Fe}_{3-\mathrm{x}} \mathrm{Ti}_{\mathrm{x}} \mathrm{O}_{4} \mathrm{NPs}$ (0.61 g) were dispersed in pyridine $(20 \mathrm{ml})$ under ultrasonication for about $30 \mathrm{~min}$. Then, a small amount of sodium metal, 3-chloropropyltrimethoxysilane (1 $\mathrm{ml}, 5.5 \mathrm{mmol})$, and a solution of tetrabutylammonium asparaginate $(2.04 \mathrm{~g}$, $5.5 \mathrm{mmol}$ in $5 \mathrm{ml}$ of chloroform) were added into the reaction mixture under argon atmosphere. The resulted mixture was ultrasonicated for $20 \mathrm{~min}$. Eventually, the reaction mixture was stirred under reflux condition at $383 \mathrm{~K}$ for $24 \mathrm{~h}$. At the end of this time, the modified NPs were separated using a magnetic bar, washed with ethanol, and dried in reduced pressure at room temperature to afford a light brown powder (Scheme 2).
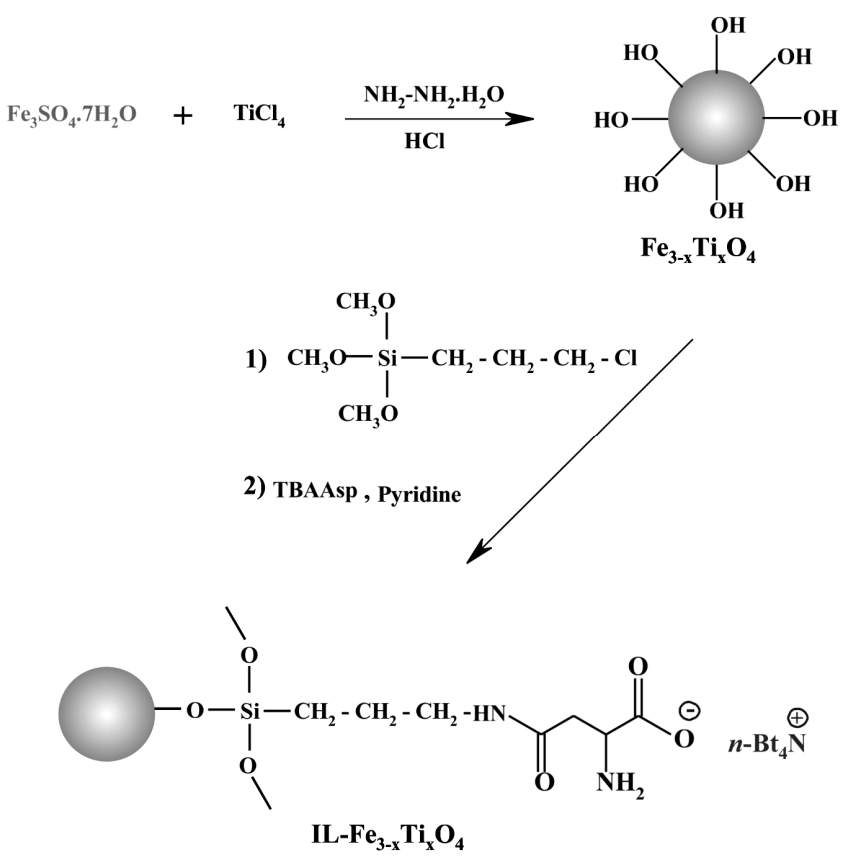

Scheme 2. Synthesis of IL-functionalized $\mathrm{Fe}_{3-\mathrm{x}} \mathrm{Ti}_{\mathrm{x}} \mathrm{O}_{4} \mathrm{MNPs}$

\subsubsection{Typical procedure for the synthesis of 2,3-dihydroquinazolin-4(1H)-one derivatives}

A 10-ml round-bottom flask was charged with 4chloroaniline (or ethylamine) (1 mmol), $1 \mathrm{H}$ benzo[d][1,3]oxazine-2,4-dione; 2H-3,1-benzoxazine$2,4(1 H)$-dione (isatoic anhydride) $(0.163 \mathrm{~g}, 1 \mathrm{mmol})$, aldehyde $(1 \mathrm{mmol})$, and IL-functionalized $\mathrm{Fe}_{3-\mathrm{x}} \mathrm{Ti}_{\mathrm{x}} \mathrm{O}_{4}$ catalyst $(0.01 \mathrm{~g})$. The mixture was stirred at $353 \mathrm{~K}$ under solvent-free condition for an appropriate time (vide Table 2). After completion of the reaction as monitored by a tine layer chromatography (TLC), the mixture was cooled to room temperature, diluted with ethanol $(10 \mathrm{ml})$, and stirred for other $10 \mathrm{~min}$. Then, the catalyst was separated magnetically simply using an external magnetic bar. The crude product was recrystallized from ethanol to obtain the pure product. All the synthesized products $\mathbf{4 a - j}$ were known compounds which were characterized by their melting points and spectral (FTIR, ${ }^{1} \mathrm{H}$ and ${ }^{13} \mathrm{C}$ NMR) analyses and compared with corresponding reported data as summarized in Table 2.

\subsubsection{Selected analytical data}

3-(4-Chlorophenyl)-2-phenyl-2,3-

dihydroquinazolin-4(1H)-one (4a). Mp. 492-495 K, FTIR (KBr) v: 3298, 3064, 2834, 1633,1612, 1511, 1491, 1394, $754 \mathrm{~cm}^{-1}$. ${ }^{1} \mathrm{H}$ NMR $\left(400 \mathrm{MHz}, \mathrm{DMSO}-d_{6}\right): 6.39(\mathrm{~s}, 1 \mathrm{H}$, $\mathrm{CH})$, 6.83-7.78 (m, 14H, NH and Ar-H) ppm. ${ }^{13} \mathrm{C}$ NMR $\left(100 \mathrm{MHz}, \mathrm{DMSO}-d_{6}\right): 72.4,114.7,114.9,117.5,126.6$, $127.9,128.0,128.4,128.5,128.6,130.1,133.9,139.4$, $140.2,146.6,162.3 \mathrm{ppm}$.

3-(4-Chlorophenyl)-2-(4-methylphenyl)-2,3-

dihydroquinazolin-4(1H)-one (4b). Mp. 529-532 K, FTIR(KBr)v: 3302, 3069, 2952, 1652, 1634, 1608, 1507, 1491, 1387, 752, 694, 576 $\mathrm{cm}^{-1}$. ${ }^{1} \mathrm{H}$ NMR $(400 \mathrm{MHz}$, DMSO- $\left.d_{6}\right): 2.22\left(\mathrm{~s}, 3 \mathrm{H}, \mathrm{CH}_{3}\right), 6.26(\mathrm{~s}, 1 \mathrm{H}, \mathrm{CH}), 6.74-7.72$ $(\mathrm{m}, 13 \mathrm{H}, \mathrm{NH}$ and $\mathrm{Ar}-\mathrm{H}) \mathrm{ppm} .{ }^{13} \mathrm{C} \mathrm{NMR}(100 \mathrm{MHz}$, DMSO- $\left.d_{6}\right) \delta: 20.5,72.2,114.7,115.0,117.4,126.5$, $127.9,128.3,128.4128 .9,130.0,133.8,137.3,137.7$, $139.5,146.6,162.3 \mathrm{ppm}$.

3-(4-Chlorophenyl)-2-(4-fluorophenyl)-2,3-

dihydroquinazolin-4(1H)-one (4c). Mp. 514-517 K, FTIR (KBr) v: 3302, 3061, 3181, 2929, 1639, 1610, 1507, 1491, $1387,757 \mathrm{~cm}^{-1} .{ }^{1} \mathrm{H}$ NMR (400 MHz, DMSO- $\left.d_{6}\right): 6.35(\mathrm{~s}$, $1 \mathrm{H}, \mathrm{CH}), \quad 6.76-7.72(\mathrm{~m}, 13 \mathrm{H}, \quad \mathrm{NH}$ and $\mathrm{Ar}-\mathrm{H})$ ppm. ${ }^{13} \mathrm{C}$ NMR (100 MHz, DMSO- $\left.d_{6}\right): 71.8,114.8,115.1$, $115.3,117.6,127.9,128.2,128.5,128.9,130.2,133.9$, $136.4,139.2,146.6,162.3,163.1 \mathrm{ppm}$.

2-(2-Chlorophenyl)-3-ethyl-2,3-dihydroquinazolin4(1H)-one (4h). Mp. 413-415 K, FTIR (KBr)v: 3267, 3032, 1620, 1580, 1523, 1470, 1324, $750 \mathrm{~cm}^{-1}$. ${ }^{1} \mathrm{H}$ NMR $\left(400 \mathrm{MHz}, \mathrm{DMSO}-d_{6}\right) \delta: 1.37-1.40\left(\mathrm{~d}, 3 \mathrm{H}, \mathrm{CH}_{3}\right), 2.78-$ $2.92\left(\mathrm{~m}, 1 \mathrm{H}, \mathrm{CH}_{2}\right), 3.71-4.20\left(\mathrm{~m}, 1 \mathrm{H}, \mathrm{CH}_{2}\right), 5.00-5.04$ (s, $1 \mathrm{H}, \mathrm{NH}), 6.11$ (s, 1H, CH), 6.45-8.05 (m, 8H, Ar-H) ppm. 3-Ethyl-2-phenyl-2,3-dihydroquinazolin-4(1H)-one (4i). Mp. 407-409 K, FTIR (KBr) v: 3265, 3032, 2969, 1619, 1577, 1469, 1323, $750 \mathrm{~cm}^{-1} .{ }^{1} \mathrm{H}$ NMR $(400 \mathrm{MHz}$, DMSO- $\left.d_{6}\right) \delta: 1.08-1.23\left(\mathrm{~d}, 3 \mathrm{H}, \mathrm{CH}_{3}\right), 2.84-2.98(\mathrm{~m}, 1 \mathrm{H}$, $\left.\mathrm{CH}_{2}\right), 3.83-3.97\left(\mathrm{~m}, 1 \mathrm{H}, \mathrm{CH}_{2}\right), 4.63(\mathrm{~s}, 1 \mathrm{H}, \mathrm{NH}), 5.76(\mathrm{~s}$, $1 \mathrm{H}, \mathrm{CH}), 6.50-7.95(\mathrm{~m}, 9 \mathrm{H}, \mathrm{Ar}-\mathrm{H}) \mathrm{ppm}$.

3-Ethyl-2-(naphthalen-1-yl)-2,3-

dihydroquinazolin-4(1H)-one (4j). Mp. 407-409 K, FTIR 
(KBr) v: 3312, 3058, 2980, 1629, 1612, 1577, 1488, $11414,778 \mathrm{~cm}^{-1} .{ }^{1} \mathrm{H}$ NMR $\left(400 \mathrm{MHz}, \mathrm{DMSO}-d_{6}\right) \delta: 1.21-$ $1.31\left(\mathrm{~d}, 3 \mathrm{H}, \mathrm{CH}_{3}\right), 2.73-2.84\left(\mathrm{~m}, 1 \mathrm{H}, \mathrm{CH}_{2}\right), 3.98-4.06(\mathrm{~m}$, $\left.1 \mathrm{H}, \mathrm{CH}_{2}\right), 4.55(\mathrm{~s}, 1 \mathrm{H}, \mathrm{CH}), 6.42-8.41(\mathrm{~m}, 12 \mathrm{H}, \mathrm{NH}$ and Ar-H) ppm.

\section{Results and Discussion}

\subsection{Characterization}

\section{of the IL-Functionalized $\mathrm{Fe}_{3-\mathrm{x}} \mathrm{Ti}_{\mathrm{x}} \mathrm{O}_{4} \mathrm{NPs}$}

The FTIR spectroscopy was employed to investigate the successful fabrication of the ILfunctionalized $\mathrm{Fe}_{3-\mathrm{x}} \mathrm{Ti}_{\mathrm{x}} \mathrm{O}_{4}$ nanocatalyst. The FTIR spectra of the TBAAsp (a) $\mathrm{Fe}_{3-\mathrm{x}} \mathrm{Ti}_{\mathrm{x}} \mathrm{O}_{4} \mathrm{NPs}$ (b), and ILfunctionalized $\mathrm{Fe}_{3-\mathrm{x}} \mathrm{Ti}_{\mathrm{x}} \mathrm{O}_{4} \mathrm{NPs}$ (c) are shown in Fig. 1. The FTIR spectrum of the TBAAsp (Fig. 1a) shows the characteristic stretching vibrations of $-\mathrm{NH}_{2}$ at 3383$3295 \mathrm{~cm}^{-1}$ region, aliphatic $\mathrm{C}-\mathrm{H}$ stretching vibrations at 2962 and $2875 \mathrm{~cm}^{-1}$, and the carbonyl stretching vibrations of amide and carboxylate at 1667 and $1578 \mathrm{~cm}^{-1}$, respectively. The bands at 1468 and $1366 \mathrm{~cm}^{-1}$ are related to the $-\mathrm{CH}$ bending vibrations. The FTIR spectrum of $\mathrm{Fe}_{3-\mathrm{x}} \mathrm{Ti}_{\mathrm{x}} \mathrm{O}_{4}$ NPs exhibited a broad vibrational band at $3418 \mathrm{~cm}^{-1}$ that related to the surface hydroxyl stretching vibration. The stretching vibration of $\mathrm{Fe}-\mathrm{O}$ and $\mathrm{Ti}-\mathrm{O}$ appeared at 587 and $735 \mathrm{~cm}^{-1}$, respectively.

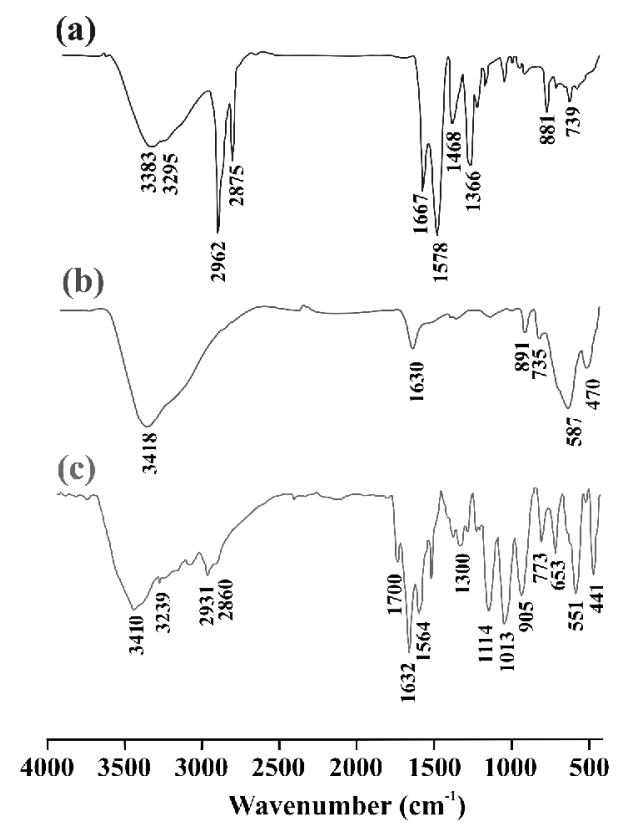

Fig. 1. FTIR spectra of TBAAsp (a), $\mathrm{Fe}_{3-\mathrm{x}} \mathrm{Ti}_{\mathrm{x}} \mathrm{O}_{4} \mathrm{NPs}(\mathrm{b})$, and IL-functionalized $\mathrm{Fe}_{3-\mathrm{x}} \mathrm{Ti}_{\mathrm{x}} \mathrm{O}_{4}$ nanocatalyst (c)

The successful modification of $\mathrm{Fe}_{3-\mathrm{x}} \mathrm{Ti}_{\mathrm{x}} \mathrm{O}_{4}$ NPs using silan coupling agent followed by TBAAsp is confirmed through the appearance of new characteristic band in the FTIR spectrum of the IL-functionalized $\mathrm{Fe}_{3-\mathrm{x}} \mathrm{Ti}_{\mathrm{x}} \mathrm{O}_{4}$ NPs as follows: the stretching vibrations of $\mathrm{C}-$ $\mathrm{H}$ at 2931 and $2860 \mathrm{~cm}^{-1}$, and the carbonyl stretching vibrations of amide and carboxylate at 1632 and $1564 \mathrm{~cm}^{-1}$, respectively. In addition, the stretching vibrations of $\mathrm{Fe}-\mathrm{O}$ and $\mathrm{Ti}-\mathrm{O}$ at 587 and $735 \mathrm{~cm}^{-1}$, respectively are shifted to relatively lower frequencies $\left(551\right.$ and $653 \mathrm{~cm}^{-1}$, respectively) after modification process. This phenomenon is originated from the reduced $\pi$-interaction between metal atoms and the non-bonding electrons on the oxygen atoms that lead to formation of $\mathrm{Fe}-\mathrm{O}-\mathrm{Si}$ and Ti-O-Si groups. These FTIR spectra clearly confirm the successful synthesis of IL-functionalized $\mathrm{Fe}_{3-\mathrm{x}} \mathrm{Ti}_{\mathrm{x}} \mathrm{O}_{4} \mathrm{NPs}$.

Further structural information obtained from other analytical techniques including energy dispersive X-ray (EDX) spectroscopy, scanning electron microscopy (SEM), vibrating sample magnetometer (VSM) measurement, as well as thermal gravimetric (TGA) and derivative thermal gravimetric (DTA) analyses have been previously reported [54].

\subsection{Catalytic Activity of the IL-Functionalized $\mathrm{Fe}_{3-\mathrm{x}} \mathrm{Ti}_{\mathrm{x}} \mathrm{O}_{4}$}

Primarily, in order to optimize the experimental conditions in terms of the reaction time and yield, the onepot three-component reaction between benzaldehyde, 4chloroaniline, and isatoic anhydride was chosen as a model reaction. The results obtained are summarized in Table 1. The experimental data revealed that the optimal condition is achieved when the reaction was performed using $10 \mathrm{mg}$ of the nanomagnetic catalyst at $353 \mathrm{~K}$ under solvent-free condition (entry 11). No improvements in the reaction time and yield were observed using higher (entries 3 and 10) or lower (entry 12) amounts of the catalyst under the same conditions. The indispensability of the IL-functionalized $\mathrm{Fe}_{3-\mathrm{x}} \mathrm{Ti}_{\mathrm{x}} \mathrm{O}_{4} \mathrm{NPs}$ as the catalyst in the reaction was approved by performing the reaction in the absence of the catalyst which resulted in no detectable amount of the respective product (entry 13).

In regard to the high catalytic performance of ILfunctionalized $\mathrm{Fe}_{3-\mathrm{x}} \mathrm{Ti}_{\mathrm{x}} \mathrm{O}_{4}$ NPs presented in the model reaction, the scope and generality of this reaction was investigated using variously substituted aromatic aldehydes (1a-j) with two different amines $\left(4-\mathrm{ClC}_{6} \mathrm{H}_{4} \mathrm{NH}_{2}\right.$ and $\mathrm{C}_{2} \mathrm{H}_{5} \mathrm{NH}_{2}$ ) under optimized conditions (Scheme 3, Table 2). On the basis of the experimental results illustrated in Table 2, all the reactions proceeded smoothly irrespective of the nature of the substituents to furnish the relevant products 4a-j in excellent yields (92-98\%), and reasonably low reaction times regardless of the substituent nature. In addition, it is clear that the developed ILfunctionalized $\mathrm{Fe}_{3-\mathrm{x}} \mathrm{Ti}_{\mathrm{x}} \mathrm{O}_{4} \mathrm{NPs}$ can catalyze the reaction with aliphatic amines as effectively as with anilines. 
Among the products, the known compounds are (FTIR, ${ }^{1} \mathrm{H}$ and ${ }^{13} \mathrm{C}$ NMR) data and compared with the characterized on the bases of their physical and spectral corresponding reported data (Table 2).

Optimization of the reaction parameters for synthesis of 2,3-dihydroquinazolin-4(1 H)-one derivatives using IL-functionalized $\mathrm{Fe}_{3-\mathrm{x}} \mathrm{Ti}_{\mathrm{x}} \mathrm{O}_{4} \mathrm{MNPs}$ as the catalyst

\begin{tabular}{|c|c|c|c|c|c|}
\hline & 3 & & 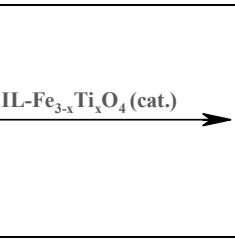 & $\stackrel{\text { O }}{11}$ & \\
\hline Entry & Solvent & Catalyst, mg & Temperature, $\mathrm{K}$ & Time, $\min$ & Isolated yield, $\%$ \\
\hline 1 & Solvent-free & 30 & 298 & 180 & 30 \\
\hline 2 & Solvent-free & 30 & 333 & 120 & 65 \\
\hline 3 & Solvent-free & 30 & 353 & 60 & 83 \\
\hline 4 & Solvent-free & 30 & 373 & 70 & 80 \\
\hline 5 & Solvent-free & 30 & 383 & 70 & 73 \\
\hline 6 & $\mathrm{EtOH}$ & 30 & 353 & 180 & 20 \\
\hline 7 & $\mathrm{H}_{2} \mathrm{O}$ & 30 & 353 & 180 & 15 \\
\hline 8 & $\mathrm{CH}_{3} \mathrm{CN}$ & 30 & 353 & 120 & 27 \\
\hline 9 & $\mathrm{EtOH} / \mathrm{H}_{2} \mathrm{O}(1: 1)$ & 30 & Reflux & 150 & 51 \\
\hline 10 & Solvent-free & 20 & 353 & 60 & 86 \\
\hline 11 & Solvent-free & 10 & 353 & 52 & 92 \\
\hline 12 & Solvent-free & 5 & 353 & 70 & 80 \\
\hline 13 & Solvent-free & No catalyst & 353 & 120 & trace \\
\hline
\end{tabular}

Reaction conditions: benzaldehyde $(0.106 \mathrm{~g}, 1 \mathrm{mmol}), 4$-chloroaniline $(0.128 \mathrm{~g}, 1 \mathrm{mmol})$, isatoic anhydride $(0.163 \mathrm{~g}$, $1 \mathrm{mmol})$, solvent $(5 \mathrm{ml})$.

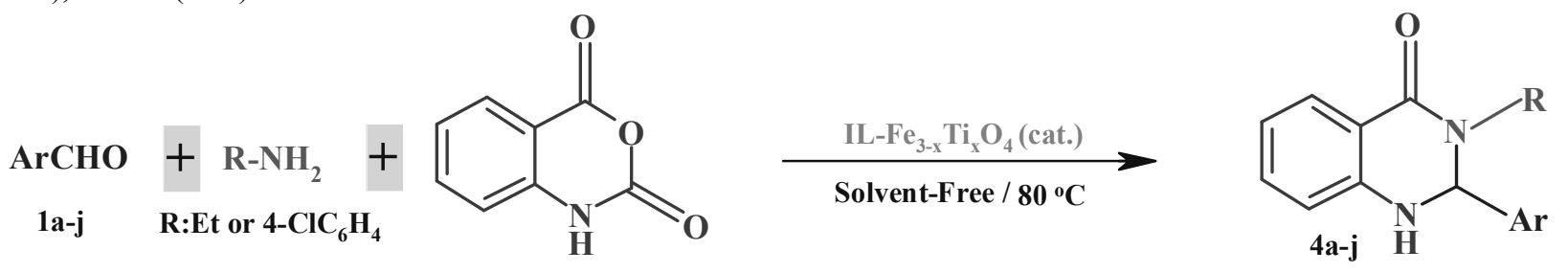

Scheme 3. $\mathrm{IL}_{-} \mathrm{Fe}_{3-\mathrm{x}} \mathrm{Ti}_{\mathrm{x}} \mathrm{O}_{4}$ MNPs-catalyzed synthesis of 2,3-dihydroquinazolin-4(1H)-ones 4a-j

Table 2

Synthesis of 2,3-dihydroquinazolin-4(1H)-ones catalyzed by $\mathrm{IL}-\mathrm{Fe}_{3-\mathrm{x}} \mathrm{Ti}_{\mathrm{x}} \mathrm{O}_{4} \mathrm{MNPs}$ under solvent free condition

\begin{tabular}{|c|c|c|c|c|c|c|c|}
\hline \multirow{2}{*}{ Entry } & \multirow{2}{*}{$\mathrm{Ar}$} & \multirow{2}{*}{$\mathrm{R}$} & \multirow{2}{*}{ Product } & \multirow{2}{*}{ Time, min } & \multirow{2}{*}{ Isolated pure yield, \% } & \multicolumn{2}{|c|}{ Mp, K } \\
\cline { 5 - 8 } & & & & & & Found & Reported [44, 56] \\
\hline 1 & $\mathrm{C}_{6} \mathrm{H}_{5}$ & $4-\mathrm{ClC}_{6} \mathrm{H}_{4}$ & $\mathbf{4 a}$ & 52 & 92 & $492-495$ & $491-493$ \\
\hline 2 & $4-\mathrm{MeC}_{6} \mathrm{H}_{4}$ & $4-\mathrm{ClC}_{6} \mathrm{H}_{4}$ & $\mathbf{4 b}$ & 85 & 96 & $529-532$ & $531-533$ \\
\hline 3 & $4-\mathrm{FC}_{6} \mathrm{H}_{4}$ & $4-\mathrm{ClC}_{6} \mathrm{H}_{4}$ & $\mathbf{4 c}$ & 48 & 94 & $517-519$ & $516-518$ \\
\hline 4 & $3-\mathrm{NO}_{2} \mathrm{C}_{6} \mathrm{H}_{4}$ & $4-\mathrm{ClC}_{6} \mathrm{H}_{4}$ & $\mathbf{4 d}$ & 85 & 97 & $520-522$ & $523-524$ \\
\hline 5 & $4-\mathrm{NO}_{2} \mathrm{C}_{6} \mathrm{H}_{4}$ & $4-\mathrm{ClC}_{6} \mathrm{H}_{4}$ & $\mathbf{4 e}$ & 90 & 94 & $526-528$ & $529-531$ \\
\hline 6 & $4-\mathrm{BrC}_{6} \mathrm{H}_{4}$ & $4-\mathrm{ClC}_{6} \mathrm{H}_{4}$ & $\mathbf{4 f}$ & 85 & 98 & $514-517$ & $525-527$ \\
\hline 7 & $4-\mathrm{HOC}_{6} \mathrm{H}_{4}$ & $4-\mathrm{ClC}_{6} \mathrm{H}_{4}$ & $\mathbf{4 g}$ & 85 & 92 & $483-485$ & $539-541$ \\
\hline 8 & $\mathrm{C}_{6} \mathrm{H}_{5}$ & $\mathrm{C}_{2} \mathrm{H}_{5}$ & $\mathbf{4 h}$ & 48 & 98 & $407-410$ & $407-409$ \\
\hline 9 & $2-\mathrm{ClC}_{6} \mathrm{H}_{4}$ & $\mathrm{C}_{2} \mathrm{H}_{5}$ & $\mathbf{4 i}$ & 35 & 98 & $406-409$ & $419-422$ \\
\hline 10 & $1-$ naphthyl & $\mathrm{C}_{2} \mathrm{H}_{5}$ & $\mathbf{4 j}$ & 46 & 96 & $460-463$ & $461-463$ \\
\hline
\end{tabular}

Reaction conditions: aldehyde $(1 \mathrm{mmol}), 4$-chloroaniline or ethylamine $(1 \mathrm{mmol})$, isatoic anhydride $(1 \mathrm{mmol})$, solvent-free, catalyst $(10 \mathrm{mg}), T=353 \mathrm{~K}$ 


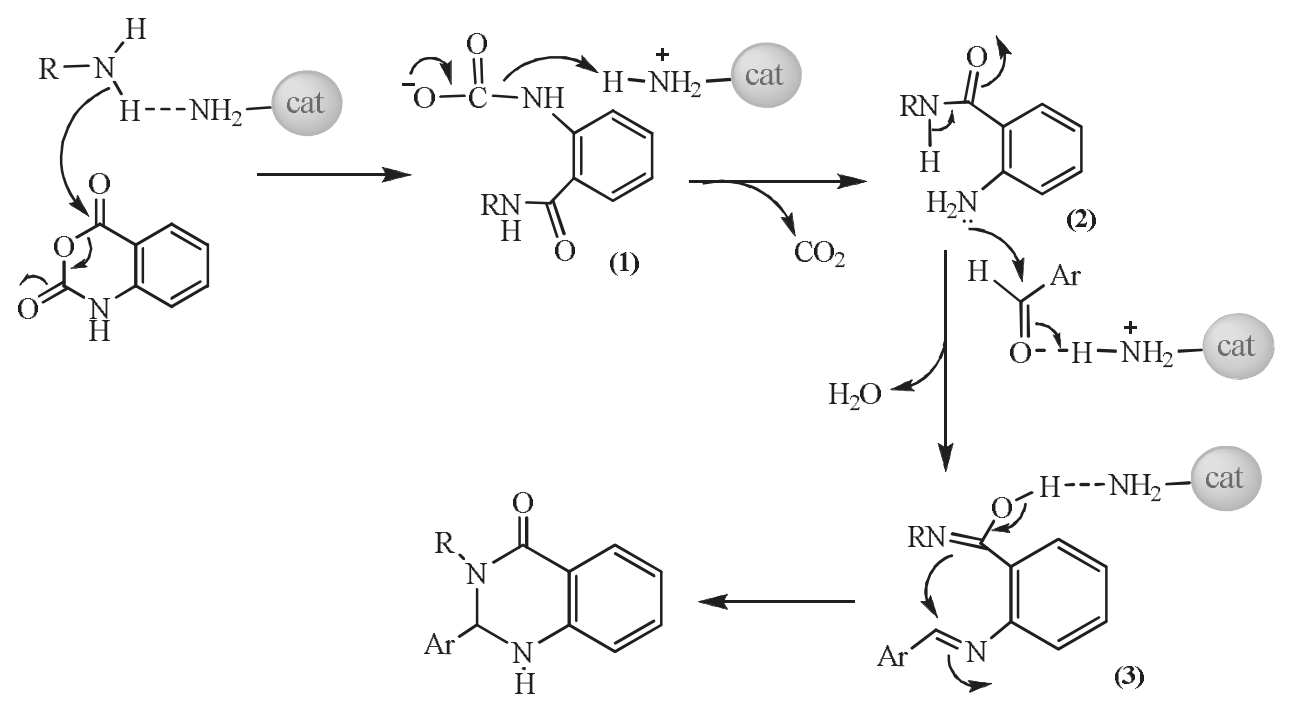

Scheme 4. A possible pathway for the synthesis of 2,3-dihydroquinazolin-4(1H)-ones catalysed by IL- $\mathrm{Fe}_{3-\mathrm{x}} \mathrm{Ti}_{\mathrm{x}} \mathrm{O}_{4} \mathrm{MNPs}$

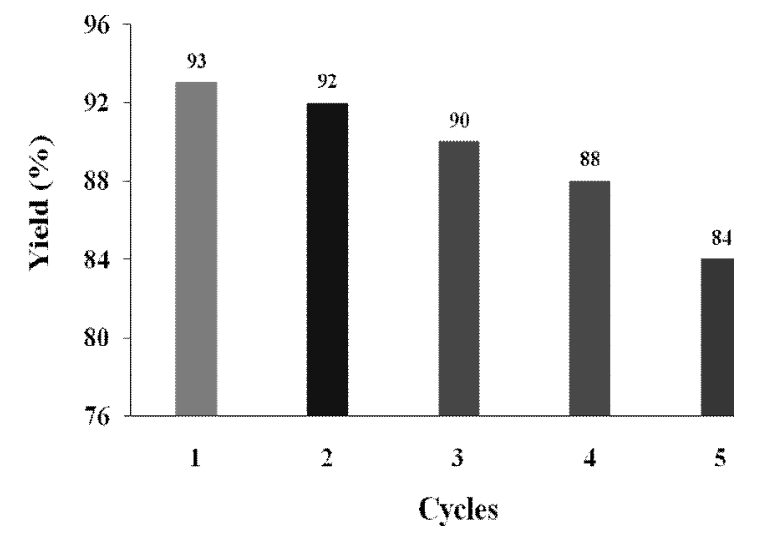

Fig. 2. Catalytic reusability of IL-functionalized $\mathrm{Fe}_{3-\mathrm{x}} \mathrm{Ti}_{\mathrm{x}} \mathrm{O}_{4} \mathrm{MNPs}$ in the synthesis of 3-(4-chlorophenyl)-2-(4-bromophenyl)-2,3-dihydroquinazolin-4(1H)-one

\subsection{Catalytic Reaction Mechanism}

A tentatively proposed mechanism to describe onepot three-component reaction between aromatic aldehydes, 4-chloroaniline (or ethylamine) and isatoic anhydride in the presence of IL-functionalized $\mathrm{Fe}_{3-\mathrm{x}} \mathrm{Ti}_{\mathrm{x}} \mathrm{O}_{4}$ NPs as a basic catalyst is depicted in Scheme 4.

First, the catalyst-accelerated deprotonation and nucleophilic attack of the amine to isatoic anhydride to produce the corresponding carbamate intermediate (1). In the next step, decarboxylation of the intermediate (1) occurs to yield the 2-aminobenzamide intermediate (2). Eventually, the catalyst-activated condensation of the intermediate (2) with the aldehyde and the intramolecular cyclization of the resulted 2-(arylideneamino)benzimidic acid intermediate (3) take place consecutively to afford the respective products (2,3-dihydroquinazolin-4(1H)ones).

\subsection{Regeneration and Reusability of a Catalyst}

The regeneration and reuse of a catalyst is important from materials science, ecological, and economic points of view. Therefore, the recycling potential of IL-functionalized $\mathrm{Fe}_{3-\mathrm{x}} \mathrm{Ti}_{\mathrm{x}} \mathrm{O}_{4} \mathrm{NPs}$ was examined using the model reaction between 4-bromophenyl aldehyde, isatoic anhydride and 4-chloroaniline under the optimal conditions. After completion of the reaction, the catalyst was magnetically separated from the reaction mixture using an external magnet. The isolated NPs were washed with ethanol three times, dried in vacuum at room temperature. The efficiencies of developed catalyst undergoing five cycles are summarized in Fig. 2. As seen, the IL-functionalized $\mathrm{Fe}_{3-\mathrm{x}} \mathrm{Ti}_{\mathrm{x}} \mathrm{O}_{4} \mathrm{NPs}$ showed a relatively good reusability for at least five fresh times. 


\section{Conclusions}

The developed IL-functionalized $\mathrm{Fe}_{3-\mathrm{x}} \mathrm{Ti}_{\mathrm{x}} \mathrm{O}_{4}$ NPs were applied as an efficient catalyst for one-pot threecomponent condensation between aromatic aldehydes, isatoic anhydride and 4-chloroaniline (or ethylamine) for the synthesis of 2,3-dihydroquinazolin-4(1H)-ones. The most important advantages of the present protocol include solvent-free and mild reaction condition, excellent yields, as well as relatively low reaction times and easy set-up. The experiments revealed that the developed IL-functionalized $\mathrm{Fe}_{3-\mathrm{x}} \mathrm{Ti}_{\mathrm{x}} \mathrm{O}_{4} \mathrm{NPs}$ has a high potential as a catalyst in organic synthesis due to easy synthesis, the uniform distribution of catalytic active species within the supported IL, high stability and selectivity, easy separation from reaction mixtures using an external magnet, and efficient recyclability and reusability.

\section{Acknowledgments}

The authors are grateful for technical supports to carry out this project from the Research Council of the Bu-Ali Sina University.

\section{References}

[1] Rossi L., Costa N., Silva F., Wojcieszak R.: Green. Chem., 2014, 16, 2906. https://doi.org/10.1039/c4gc00164h

[2] Ghasemzadeh M., Mirhosseini-Eshkevari B.: J. Chem. Res., $2015,39,380$.

https://doi.org/10.3184/174751915X14355930432579

[3] Garrett C., Prasad K.: Adv. Synth. Catal., 2004, 346, 889. https://doi.org/10.1002/adsc.200404071

[4] Lu A., Salabas E., Schth F.: Angew. Chem. Int. Edit., 2007, 46, 1222. https://doi.org/10.1002/anie.200602866

[5] Polshettiwar V., Luque R., Fihri A. et al.: Chem. Rev., 2011, 111, 3036. https://doi.org/10.1021/cr100230z

[6] Du Y., Yao F., Tuo Y., Cai M.: J. Chem. Res., 2017, 41, 725. https://doi.org/10.3184/174751917X15122516000113

[7] Bell A.: Science, 2003, 299, 1688.

https://doi.org/10.1126/science.1083671

[8] Polshettiwar V., Varma R.: Green Chem., 2010, 12, 743.

https://doi.org/10.1039/b921171c

[9] Farnoudian-Habibi A., Massoumi B., Jaymand M.: Spectrochim. Acta A, 2016, 168, 235. https://doi.org/10.1016/j.saa.2016.06.013

[10] Poorgholy N., Massoumi B., Jaymand M.: Int. J. Biol.

Macromol., 2017, 97, 654.

https://doi.org/10.1016/j.ijbiomac.2017.01.063

[11] Muller R., Laurent S., Forge D. et al.: Chem. Rev., 2008, 108, 2064. https://doi.org/10.1021/cr0306788

[12] Teja A., Koh P.: Prog. Cryst. Growth Charact. Mater., 2009,

55, 22. https://doi.org/10.1016/j.pcrysgrow.2008.08.003

[13] Barkhordarion-Mohammadi S., Safaei-Ghomi J.: Zeitschrift für Naturforschung B, 2018, 73, 17. https://doi.org/10.1515/znb-20170114
[14] Liang X., Zhong Y., Zhu S. et al.: J. Hazard. Mater., 2012, 199200, 247. https://doi.org/10.1016/j.jhazmat.2011.11.007

[15] Bliem J., Pavelec J., Gamba O. et al.: Phys Rev. B, 2015, 92, 075440. https://doi.org/10.1103/PhysRevB.92.075440

[16] Azarifar D., Abbasi Y.: Synth. Commun., 2016, 46, 745. https://doi.org/10.1080/00397911.2016.1171360

[17] Azarifar D., Abbasi Y., Badalkhani O.: J. Iran. Chem. Soc., 2016, 13, 2029. https://doi.org/10.1007/s13738-016-0920-0

[18] Gawande M., Rathi A., Nogueira I. et al.: Green Chem., 2013, 15, 1895. https://doi.org/10.1039/c3gc40457a

[19] Rajesh U., Divya, Rawat D.: RSC Adv., 2014, 4, 41323. https://doi.org/10.1039/C4RA06803C

[20] Jaymand M.: J. Polym. Res., 2011, 18, 1617.

https://doi.org/10.1007/s10965-011-9566-x

[21] Morel A., Nikitenko S., Gionnet K. et al.: ACS Nano, 2008, 2 , 847. https://doi.org/10.1021/nn800091q

[22] Safari J., Zarnegar Z.: New J. Chem., 2014, 38, 358.

https://doi.org/10.1039/C3NJ01065A

[23] Farrokhi A., Ghodrati K., Yavari I.: Catal. Commun., 2015, 63, 41. https://doi.org/10.1016/j.catcom.2014.09.046

[24] Li P., Li B., Hu H. et al.: Catal. Commun., 2014, 46, 118. https://doi.org/10.1016/j.catcom.2013.11.025

[25] Yuan C., Huang Z.: Catal. Commun., 2012, 24, 56.

https://doi.org/10.1016/j.catcom.2012.03.003

[26] Archana A., Srivastava V., Ramesh C., Ashok K.: Indian J. Chem., 2002, 41B, 2371.

[27] Ibrahim S., Abo-Kul M., Soltan M., Helal A.: Asian J. Res. Chem. Pharm. Sci., 2013, 1, 40.

[28] Srivastav M., Salahuddin M., Shantakumar S.: E-J. Chem., 2009, 6, 1055. https://doi.org/10.1155/2009/507052

[29] Atsuo B., Noriaki K., Haruhiko M. et al.: J. Med. Chem., 1996, 39, 5176. https://doi.org/10.1021/jm9509408

[30] Kumar A., Sharma S., Bajaj K. et al.: Bioorg. Med. Chem., 2003, 11, 5293. https://doi.org/10.1016/S0968-0896(03)00501-7

[31] Medina J., Johanson M., Li A. et al.: PCT Int. Appl. WO 02/083143; Chem. Abstr, 2002, 137, 337909.

[32] Daniel B., Jason W., Stephanie L. et al.: J. Dermatol. Sci., 2006, 42, 13. https://doi.org/10.1016/j.jdermsci.2005.12.009

[33] Alagarsamy V., Gopinath M., Parthiban P. et al.: Med. Chem. Res., 2011, 20, 946. https://doi.org/10.1007/s00044-010-9417-z [34] Hamel E., Lin C., Plowman J. et al.: Biochem. Pharmacol., 1996, 51, 53. https://doi.org/10.1016/0006-2952(95)02156-6 [35] Kamal A., Bharathi E., Reddy J. et al.: Eur. J. Med. Chem., 2011, 46, 691. https://doi.org/10.1016/j.ejmech.2010.12.004 [36] Kurogi Y., Inoue Y., Tsutsumi K. et al.: J. Med. Chem., 1996, 39, 1433. https://doi.org/10.1021/jm9506938

[37] Kacker I., Zaheer S.: J. Indian Chem. Soc., 1951, 28, 344.

[38] Vasudhevan S., Karunakaran R.: Int. J. ChemTech. Res., 2013, $\mathbf{5}, 2844$.

[39] Parish H., Gilliom R., Purcell W. et al.: J. Med. Chem., 1982, 25, 98. https://doi.org/10.1021/jm00343a022

[40] Mhaske S., Argade N.: Tetrahedron, 2006, 62, 9787. https://doi.org/10.1016/j.tet.2006.07.098

[41] Tinker A., Beaton H., Smith N. et al.: J. Med. Chem., 2003, 46, 913. https://doi.org/10.1021/jm0255926

[42] Dabiri M., Salehi P., Baghbanzadeh M.: Monatsh. Chem., 2007, 138, 1191. https://doi.org/10.1007/s00706-007-0635-0 [43] Darvatkar N., Bhilare S., Deorukhkar A. et al.: Green Chem. Lett. Rev., 2010, 3, 301.

https://doi.org/10.1080/17518253.2010.485581

[44] Zhang Z., Lü H., Yang S., Gao J.: J. Comb. Chem., 2010, 12, 643. https://doi.org/10.1021/cc100047j 
[45] Davoodnia A., Allameh S., Fakhari A., Tavakoli-Hoseini N.:

Chin. Chem. Lett., 2010, 21, 550.

https://doi.org/10.1016/j.cclet.2010.01.032

[46] Esmaeilpour M., Javidi J., Zahmatkesh S., Fahimi N.: Monatsh. Chem., 2017, 148, 947. https://doi.org/10.1007/s00706-016-1832-5

[47] Alinezhad H., Tajbakhsh M., Ghobati N.: Res. Rev. Mater. Sci. Chem., 2014, 3, 123.

[48] Baghbanzadeh M., Salehi P., Dabiri M., Kozehgarya G.: Synthesis, 2006, 2, 344. https://doi.org/10.1055/s-2005-924766

[49] Dabiri M., Salehi P., Otokesh S. et al.: Tetrahedron Lett., 2005, 46, 6123. https://doi.org/10.1016/j.tetlet.2005.06.157

[50] Salehi P., Dabiri M., Baghbanzadeh M., Bahramnejad M.:

Synth. Commun., 2006, 36, 2287.

https://doi.org/10.1080/00397910600639752

[51] Chen J., Wu D., He F. et al.: Tetrahedron Lett., 2008, 49, 3814. https://doi.org/10.1016/j.tetlet.2008.03.127

[52] Salehi P., Dabiri M., Zolfigol M., Baghbanzadeh M.: Synlett., 2005, 7, 1155. https://doi.org/10.1055/s-2005-865200

[53] Allen C., Richard P., Ward A. et al.: Tetrahedron Lett., 2006, 47, 7367. https://doi.org/10.1016/j.tetlet.2006.08.007

[54] Azarifar D., Badalkhani O., Abbasi Y.: Appl. Organomet. Chem., 2018, 32, e3949. https://doi.org/10.1002/aoc.3949

[55] Yang S., He H., Wu D. et al.: Appl. Catal. B, 2009, 89, 527. https://doi.org/10.1016/j.apcatb.2009.01.012

[56] Su W., Yang B.: Aust. J. Chem., 2002, 55, 695.

https://doi.org/10.1071/CH02117

Received: June 05, 2018 / Revised: September 11, 2018 / Accepted: December 11, 2018

\section{ЙОННІ РІДКОФУНКЩІОНАЛІЗОВАНІ ТИТАНОМАГНЕТИТНІ НАНОЧАСТИНКИ ЯК ЕФЕКТИВНИЙ I ВІДНОВЛЮВАЛЬНИЙ КАТАЛІЗАТОР ЗЕЛЕНОГО СИНТЕЗУ 2,3-ДИГІДРОХІНАЗОЛІН-4(1Н)-ОНУ}

\begin{abstract}
Анотація. Методом ко-осадження синтезовано наночастинки титаномагнетиту $\left(\mathrm{Fe}_{3-x} \mathrm{Ti}_{x} \mathrm{O}_{4} \mathrm{NPS}\right)$ та проведено їх функиіоналізаиію з використанням 3-триметоксилілпропілхлоридного силанового агента $i$ аспарагінату тетрабутиламонію за допомогою нового однореакторного синтезу з метою одержсання $\mathrm{Fe}_{3-x} \mathrm{Ti}_{x} \mathrm{O}_{4} \mathrm{NPS}$, модифікованих йонною рідиною. Встановлено, щзо синтезовані NPs є ефективним $i$ відновлювальним нанокаталізатором однореакторного трикомпонентного синтезу 2,3-дигідрохіназолін-4(1Н)-ону без використання розчинників. Показано, щзо легкість магнітної сепарації та ефективна відновлюваність каталізатора, високі виходи реакцій, малий час реакиії, та відсутність розчинників $\epsilon$ найважливішими перевагали нового методу. Синтезовані $\mathrm{Fe}_{3-}$ ${ }_{x} \mathrm{Ti}_{x} \mathrm{O}_{4} \mathrm{NPS}$ можна використовувати як нанокаталізатор $y$ промисловості.
\end{abstract}

Ключові слова: йонна рідина, наночастинки титаномагнетиту, нанокаталізатор, зелена хімія, органічний синтез. 